\title{
On Marine Spirit in William Golding's * To the Ends of the Earth
}

\author{
Kanshuai Jiang ${ }^{1}$,2*; Yalun $\mathrm{HaO}^{2}$ \\ ${ }^{1}$ College of Literature and Journalism, Xiangtan University, Xiangtan, Hunan 411105, China. \\ ${ }^{2}$ School of Foreign Languages, Hunan University of Humanities, Science and Technology, Loudi, Hunan 417000, \\ China. \\ *Corresponding author. Kanshuai Jiang.Email: jkshuai2018@126.com
}

\begin{abstract}
William Golding is one of the most influential contemporary British writers. Under the influence of maritime civilization, he has an indissoluble bond with the ocean. In To the Ends of the Earth, the ship is regarded as a state and the voyage compared with life, demonstrating a profound picture of life and colourful marine culture with aesthetic significance. The spirit of exploration and pioneering, responsibility, solidarity and cooperation, openness and inclusiveness, unity of knowledge and practice, etc. revealed in the novel as an illustration of Englishness, has certain enlightenment and reference significance for enhancing the marine consciousness of the people, flourishing the marine culture and boosting the construction of a maritime power.
\end{abstract}

Keywords: William Golding, To the Ends of the Earth, marine spirit.

\section{INTRODUCTION}

To the Ends of the Earth, an important work of William Golding, including Rites of Passage, Close Quarters and Fire Down Below. Rites of Passage wins the 1980 Booker Prize, making another peak in his career. Close Quarters is distinct in style among Golding's novels, described by John Carey as Golding's "happiest novel". The Trilogy, which spanned the entire 1980s, is published in 1991 under the title To the Ends of the Earth and its influence was further enlarged after made into a BBC TV drama in 2005. Since the publication of the Trilogy, critics have conducted indepth and comprehensive study on the work, covering culture, history, politics, society, religion and other aspects, showing a trend of diversified development in the perspective, breadth and depth of research. However, the study of this work from the perspective of marine spirit is relatively weak, which is the cause of this paper.

\section{ENGLAND, THE SEA AND WILLIAM GOLDING}

As an island country, Britain's unique geographical condition and cultural heritage have profoundly influenced the history of the country. After the great geographical discovery of 1492, the worship of primitive wealth and various productive resources prompted the Western powers to embark on sea voyages and explore the new world at all costs. Since modern times, navigation has promoted the formation and development of the British expansion culture, and overseas colonization has finally established its longterm maritime dominance and achieved the glory of "The Empire on Which the Sun Never Sets". Throughout Britain's modern history, the ocean has played an indispensable role with oceanity as one of the most prominent features of Britishness. Island environment and surrounding marine resources provided favourable conditions for navigation technology, naval development, overseas expansion and prosperity of overseas trade. The love of island made the British imaginative and pioneering, which had a far-reaching influence on its literature.

With the development and prosperity of capitalism in Britain, navigation became increasingly important as a major means of foreign communication. Throughout the oceangoing voyage history of Britain, from the 15th century to the 19th century, the British never stopped exploring the world. From being on the edge of the stage in the great discovery of the world to gradually occupying the centre, navigation became an effective way to solve domestic problems. In the course of twists 
and turns of navigation, comprehensive national strength and navigation have mutually reinforced. The voyage is not only the exploration and plunder of the unknown world, but always full of contests with nature, competition with foreign nations, and even cruel battles.

William Golding is one of the most influential novelists in modern England. The sea is an integral part of his life. During World War II, he served in the Royal Navy for five years, taking part in major battles such as the sinking of the Bismarck and the D-Day landings, where he was commissioned as a lieutenant. The experience formed an ocean affection that lasts lifelong. He loves the ocean and sailing in his spare time. His rich sea experience and ocean (sailing) writing reflect his life attitude of the unity of knowledge and practice and the ecological consciousness of harmonious coexistence between man and the ocean. The profound accumulation of tradition and individual makes the ocean an important source of inspiration for Golding. He wrote 13 fictions, five of which dealt with the sea. "If he did not like literary jargon so much, the sea could be called a subtext of his works, and chapters could be written on the sea/see dichotomy from his point of view." [1] Great importance has been attached to the mystery of the ocean in Golding' s works. The mystery of the ocean has been written in his famous work Lord of the Flies, To the Ends of the Earth in later years, and in his 1983 Nobel Prize for Literature award speech. In Golding's works, the vast and deep ocean was described as a paradise of freedom away from the real world and as a stage where human nature can be adequately displayed. The ocean is also like a mirror, reflecting the complex society.

\section{THE WRITING OF MARINE CULTURE IN TO THE ENDS OF THE EARTH}

To the Ends of the Earth, a narrative work written by Golding in his later years, consisting of three novels, Rites of Passage (1980), Close Quarters (1987) and Fire Down Below (1989). Set during the Napoleonic Wars (1803-1815) and narrated by the aristocratic young Talbot, the novel tells an extraordinary story of a warship's difficult voyage to Australia. The growing tensions and misfortunes aboard the ancient ship have made it a classic of marine literature and one of Golding's finest achievements.

The space of the story is closed and full of risks. Just as Michel Foucault said, "A ship is a floating space, not a place of place. It exists independently, closes itself, and at the same time gives itself to the infinite sea." [2] One of the protagonists of the story, Colley, described the sailing ship as "suspended between the land below the waters and the sky like a nut on a branch or a leaf on a pond!" [3], showing the tiny and powerless of man in front of nature.

\subsection{The Ship of State}

Human exploration of nature has never stopped, especially since the great geographical discovery of 1492, the boundaries of human cognition have been greatly expanded. As an island country and one of the earliest and most developed countries of capitalism, the development of capitalist economy and endless pursuit of profit have greatly promoted the exploration of overseas markets and the origin place of raw materials. The essence of navigation is to explore overseas and expand territory, which is the inherent requirement of capital expansion and the manifestation and enhancement of national strength. The prosperity of maritime trade also stimulated the domestic economy and the occurrence of industrial revolution, reflecting the natural attribute of adventure and expansion of maritime nations. British rulers once justified their aggression by saying: "The sea is open, in the sense that no people can exclude the expansion of any extendable part of the sea by another." [4] In this sense, the navigation voyage in To the Ends of the Earth reflects the will and power of the Great Britain. The warship in the fiction is the ship of the state, and Golding's "ship of state" thought is the inheritance of western navigation tradition.

The story took place during the Napoleonic Wars. Facing the possibility of encountering with a French ship, the crew showed the fearless spirit of never cowering, fighting to the end, and vowing to survive and die together with the ship. Writing about the imagination of the battle and the crew's fearless struggle in coping with the storm aims to illustrate the concept of a community with a shared destiny and to meet challenges by constructing the French as the "other" in adverse scenarios. In this way, the sense of responsibility and the readers' patriotic enthusiasm can be effectively aroused.

In the novel, the hero Talbot repeatedly expressed his strong desire to build a powerful navy and national sea lane, together with the mention of various plants from all over the world, such as geranium display the author's imagination of sea power and empire construction, as well as his dream of the empire.

\subsection{The Ship of Society}

Edmund Talbot, the narrator of To the Ends of the Earth, is an aristocratic young man who travels to a high post in the colonies. His log satirizes various characters on board. Mr. Prettiman, an atheist and rationalist, cruises the decks with a loaded musket, hoping to disprove Coleridge's "The Rime of the Ancient Mariner" superstition that shooting an albatross will unavoidably bring about a navigable disaster. In this playful way, Golding shows his identification with the satire and rationalism of the western nautical literature 
tradition. There is also a Miss Granham, a frank and warm-hearted intellectual female, who hides her past as a governess, showing the complexity and hypocrisy of human nature. Talbot succumbed to the temptation to see through the disguise and, while the other passengers and crew were on deck watching the passage rites of the equator, seized the opportunity to engage in a mundane sexual orgy with Zenobia in the cabin, which was both a manifestation of reckless masculinity and a hint of moral weakness and personality immaturity.

He was most attracted to a young clergyman, Colley, a lower middle-class man. Talbot found his coarse appearance and obsequious manner repulsive. Due to captain Anderson's hatred of the priest, the ship formed a kind of atmosphere that priest may bring bad luck to sailing. The priest was persecuted after could not help but issue an exclamation: "This is a Godless vessel!" [3]. Taken as a whole, however, the sacrilegious actions of the priest are self-degrading, with bitter irony.

However, when Colley is publicly humiliated by Captain Anderson, Talbot's sense of justice and gentlemanly manner is aroused and determined to protect Colley. Anderson, fearing that his tyranny might be noticed by those in power, relented toward Colley. Unfortunately, this false signal to Colley led him to put on his robes and venture into the bow of the ship where the lower-class settlers and crew were placed, intending to lead them on a pilgrimage. Disaster ensued when Colley was seen drunk, scantily clad, clearly delighted, grabbing a half-naked sailor and making a spectacle of himself in public. He did not show up for the next few days, lying face down on the bed, seemingly unconscious. There is growing concern about his illness. Lieutenant Summers, an officer who had risen through the ranks, had persuaded Talbot and even Captain Anderson to come to the vicar's cabin and persuade him to wake up, but to no use, Colley remained motionless and died of shame.

Gossips among the crew suggested that Colley had engaged in homosexual acts with sailors. The investigation into Corley's death had to be shelved permanently for reasons related to the ship's safety, mainly because it was not known that a sailor had committed "buggery", which is absolutely forbidden on board.

Navigation of the fiction is in the age of sails and thus is largely subject to the weather. The ship remained for some time in doldrums (calm waters), and as she struggled into windy waters, a strong wind suddenly arose, damaging her foremast and blowing her back into still waters. One day, a ship appeared in the distance. All the passengers thought it was a French warship and were getting ready to meet the enemy until they discovered that it was the Alcyone, an English ship commanded by Sir Henry Somerset. The ship was excited by the news that the war was over. Therefore, the two ships were firmly tied together, and a carnival at sea was about to begin. Carnival made people temporarily forget the melancholy of the voyage and upended the ship's hierarchy order. Edmund met Sir Henry's ward, Marion, and immediately fell in love. To Talbot's surprise, Edmund's servant Wheeler was on board the Alcyone. He stayed in the water for four days before being found and rescued by the crew and eventually returned to his original boat. As they continued sailing, part of the keel fell off the ship, causing more damage. The passengers began to panic that the ship would sink to the bottom of the sea. Talbot found Wheeler with a gun in his cabin and, after his last brush with death, shot himself in fear of drowning.

Ship provides a stage for performances of different characters, distinguished by their proximity to each other, in which everyone is both a spectator and meanwhile being watched. Discipline and maybe punishment (rites of passage) occur at intervals. Thus, in this wooden world of various absurdities, the image of "ship of fools" and of souls is vividly evoked.

\subsection{Navigation is Life}

Navigation under Golding's pen possesses multiple symbolic significances, one of which is that Navigation is life. Sea voyage is employed by the author to demonstrate the joys and sorrows of life and the plight of human existence, which is a frequently applied metaphor in both eastern and western cultures, illustrating the universality of human survival experience and cultural commonality. In To the Ends of the Earth, most of the passengers embark on a voyage of hope for the new world, take the voyage as an important opportunity of transition from the old to the new world, realizing the positive change in life. Talbot's trip to colony is secured by his godfather for serving key position. Colley would endeavor to spread Christian thought in the new world to success. Summers, the ship's first mate, took the voyage as a chance to climb the social ladder with diligence and responsibility. Therefore, from a personal point of view, the ship in the novel is the ship of the hero's life to achieve the transformation of destiny. However, because of all the uncertainties in the long voyage, the transition of life may not be realized. Isn't that a authentic picture of our life? Navigation is a large-scale exploration activity in human history, in which the adaptation to the environment is human growth. To the Ends of the Earth highlights the expression of the unity of knowledge and action, human exploration of self and nature is synchronized. Talbot and Colley 's almost opposite life curves, one up, the other down, deeply reveal the importance of self-awareness and self-discipline for young people. In this sense, the ship in the novel is the ship of the soul, which is tortured again and again by writing about humanity, rank and desire in the voyage. 
In a similar way to Conrad's view of sailing: "He [Conrad] says elsewhere that sailing gives you peace of mind and moral discipline." [2]

The sea as destiny is another symbol of the fiction. The tragedy of Colley's death defines boundaries and transgressions of thought and action and tells a truth that a price should be paid for breaking the rule. Marion Chumley told Talbot significantly, "Young persons are like ships, Mr. Talbot. They do not decide their fate nor their destination." [5] Sailing involves many uncertainties and risks. During the voyage, the ship encountered a storm. The ship's mainmast was damaged so the course veered off. Bernet planned to secure the base by shrinking red-hot iron bars when they were cooled, which would risk a fire on the ship. Summers rejected this risky approach and advocated a conservative approach to the problem. Whereas Bernet determined longitude by measuring celestial distances, Summers relied on traditional methods and years of sailing experience to get his real-time position. The sharp contrast between the two first mates embodies the contest between rationality and sensibility, which is the author's response to the relationship between contemporary human beings and science.

On the whole, To the Ends of the Earth is tragicomedy with sadness, joy and farce elements. During the voyage, various senses of sight, hearing and taste and imaginations about the ship as musical instruments, old leather boots, and old women are proposed. Many lessons need to be learned from during the long voyage: friendship, love and life. The origin of Talbot and Summers' costume change is the symbol of friendship from Greek mythology. Golding's voyage tells of life's repression and its release: wine, sex and mores, comedy and carnival.

The inheritance of nautical culture is evident in the narrative work. Golding paid tribute to the navigation tradition in his own way. Odysseus and Coleridge are all subjects of homage. Talbot, the protagonist of the narrative, repeatedly mentions William Falconer, an important figure in British navigation history, and learns "tarry language" with the help of his Marine Dictionary, reveals his desire for environmental monitor during the voyage, and is also the author's way of paying tribute to the western maritime tradition.

\section{CONCLUSION}

The core values of the sea are closely related to the cultural characteristics of openness, adventure, expansion and competition in western civilization, as well as the optimistic, positive and romantic characters of westerners. Oceans connect the world and are closely related to other civilizations. Navigation is the main way to spread modern civilization and is closely related to the progress of human thought. Robert Foucault talks about the importance of constant meditation in the narrative of voyage. From the perspective of human evolution, the impetus of progress lies in human meditation and revelation.

To the Ends of the Earth contributes to human understanding that the western maritime culture has always been an aggressive one integrating trade and colonization. The idea that the ship is the state contributes to the understanding and cognition of the community with a shared future for mankind and the concept of global ocean governance. Under the context of globalization, countries should jointly address global ocean problems through effective international rules and extensive consultation and cooperation, and strive to achieve global harmony and sustainable development during utilization of oceans.

A ship is like a state, navigation, life. Through the application of multiple symbolic meanings of navigation, Golding linked the distant space-time narrative with comments on the world at his time, presenting a colorful and profound picture of life with aesthetic significance. Golding agrees with Conrad in that teamwork is an important aspect of the seafaring spirit. In addition, To the Ends of the Earth demonstrates the precious spirits of courage, openness, inclusiveness, and unity of knowledge with practice. The essential strength of human self-reveal gathering together as marine culture possesses a universal value, inherited from generation to generation. The marine culture in William Golding's To the Ends of the Earth provides enlightenment and reference significance to enhance the marine consciousness of people, enrich the marine culture and construct one nation's ocean voice on the world stage. The study possesses cognitive value to western society and culture. Further study concerning the work might be done on the interconnectedness between seafaring and human community with a shared future.

*Funds: 2018 Hunan Social Science Foundation Project (Research on Acculturation and Cultural Identity in the translation of Mo Yan's Novels, No. 18YBA241) ; 2020 Hunan Social Science Achievement Appraisal Committee Project (A Study of Howard Goldblatt's English Translation of Mo Yan's Novels from the Perspective of Sub-text, Social Science Union Project 2020, No.558)

\section{REFERENCES}

[1] Andrew Sinclair. William Golding's the Sea, the Sea, vol. 28.2, Twentieth Century Literature, 1982, pp.171-180.

[2] John Mack, The Sea---A Cultural History, translated by Feng Yanqun, Chen Shuying, Shanghai Translation Publishing House, 2018. 
[3] William Golding, Rites of Passage, Faber and Faber Limited, Bloomsbury House, 74-77 Great Russell Street, London WC1B 3DA, 2013.

[4] Rowse, A. L. The Expansion of Elizabethan England, New York, London: Scribner, Macmillan, 1981.

[5] William Golding, To the Ends of the Earth, Faber and Faber Limited, 3 Queen Square London WCIN 3AU, 1991. 